\title{
HABITAT SIAMANG (Symphalangus syndactylus, Raffles 1821) DI KAWASAN TERDEGRADASI TAMAN NASIONAL KERINCI SEBLAT, KABUPATEN PESISIR SELATAN
}

(Habitat of Siamang (Symphalangus syndactylus, Raffles 1821) in Degraded Area of Kerinci Seblat National Park, Pesisir Selatan Regency)

\section{Bismark, Sofian Iskandar, Reny Sawitri*, N. M. Heriyanto dan/and Yulaeka}

Pusat Penelitian dan Pengembangan Hutan, Jl. Gunung Batu No. 5 Bogor, Jawa Barat, Indonesia Tlp. (0251) 8633234; Fax (0251) 8638111

\begin{tabular}{|c|c|}
\hline Info artikel: & ABSTRACT \\
\hline $\begin{array}{l}\text { Keywords: } \\
\text { Siamang, } \\
\text { mosaic, } \\
\text { population, } \\
\text { vegetation }\end{array}$ & $\begin{array}{l}\text { Siamang gibbon (Symphalangus syndactylus, Raffles } 1821 \text { ) is highly threatened primate } \\
\text { species living in degraded habitat of Kerinci Seblat National Park. The research was } \\
\text { carried out to determine mosaic areas in the forest and buffer zone, and also supporting } \\
\text { vegetation for siamang population. The study was conducted in September and November } \\
2015 \text { by using ground control point (GCP) for mosaics coordinate and point centre count } \\
\text { (PCP) for population and vegetation data surrounding mosaic areas. Degradation in } \\
\text { national park shaped mosaics consisting of primary forest, secondary forest, agroforestry } \\
\text { land and white catechu cultivation with an average area respectively as followed } 29.30 \text { ha, } \\
7.90 \mathrm{ha}, 11.70 \text { ha and } 7.80 \text { ha; while, the average distance among the mosaics as followed } \\
486.70 \mathrm{~m}, 458.75 \mathrm{~m}, 368.75 \mathrm{~m} \text { and } 202.50 \mathrm{~m} \text {. As a consequence, the habitat of siamang was } \\
\text { fragmented. Primary forest mosaic, nonetheless, provides sufficient habitat for siamang as } \\
\text { shown by the normal population density of about } 2.45 \text { groups per } \mathrm{km}^{2} \text { or } 8.40 \text { individuals } \\
\text { per } \mathrm{km}^{2} \text {. The feeding behaviour of siamang funneling dispersed seed into degraded areas } \\
\text { as indicated by seedling density reached up to } 13,333 \text { seedlings per ha. Furthermore, forest } \\
\text { buffer zone management in the form of agroforestry land will function as an extended } \\
\text { habitat for siamang as food resources and socialization. }\end{array}$ \\
\hline \multirow{2}{*}{$\begin{array}{l}\text { Kata kunci: } \\
\text { Siamang, } \\
\text { mosaik, } \\
\text { populasi, } \\
\text { vegetasi }\end{array}$} & ABSTRAK \\
\hline & $\begin{array}{l}\text { Siamang (Symphalangus syndactylus, Raffles 1821) adalah primata yang memiliki tingkat } \\
\text { keterancaman yang tinggi, dan dijumpai di habitat terdegradasi Taman Nasional Kerinci } \\
\text { Seblat (TNKS). Penelitian ini bertujuan untuk mengetahui luasan mosaik di kawasan hutan, } \\
\text { daerah penyangga, dan vegetasi pendukung untuk populasi siamang. Penelitian } \\
\text { dilaksanakan pada bulan September dan November } 2015 \text { menggunakan metoda ground } \\
\text { control point (GCP) untuk koordinat mosaik, point centre count (PCP) untuk populasi,dan } \\
\text { data vegetasi di sekitar mosaik. Degradasi di kawasan hutan membentuk mosaik yang } \\
\text { meliputi hutan primer dan sekunder, dan kebun agroforestri dan gambir dengan luas rata- }\end{array}$ \\
\hline $\begin{array}{l}\text { Riwayat Artikel: } \\
\text { Tanggal diterima: } \\
29 \text { Agustus 2018; } \\
\text { Tanggal direvisi: } \\
\text { 24 Mei 2019; } \\
\text { Tanggal disetujui: } \\
\text { 1 Juli } 2019\end{array}$ & $\begin{array}{l}\text { rata } 29,30 \text { ha; } 7,90 \mathrm{ha} ; 11,70 \text { ha dan } 7,80 \text { ha, sedangkan jarak antar mosaik berturut-turut } \\
\text { adalah } 486,70 \mathrm{~m} \text {; } 458,75 \mathrm{~m} ; 368,75 \mathrm{~m} \text { dan } 202,50 \mathrm{~m} \text {. Kondisi ini yang membentuk } \\
\text { fragmentasi habitat siamang. Namun, mosaik hutan primer masih memberikan kecukupan } \\
\text { untuk habitat siamang, ditandai dengan populasi yang masih dalam selang kepadatan } \\
\text { normal, yaitu } 2,45 \mathrm{kelompok} \text { per } \mathrm{km}^{2} \text { atau } 8,40 \text { individu per } \mathrm{km}^{2} \text {. Perilaku siamang sebagai } \\
\text { pemakan buah-buahan menyebabkan biji-bijian menyebar di kawasan terdegradasi, } \\
\text { ditandai dengan kerapatan tingkat semai mencapai } 13.333 \text { semai per ha. Lebih lanjut, } \\
\text { pengelolaan daerah penyangga di perbatasan kawasan hutan dalam bentuk kebun } \\
\text { agroforestri memiliki fungsi sebagai areal perluasan habitat untuk sumber pakan dan tempat } \\
\text { bersosialisasi. }\end{array}$ \\
\hline
\end{tabular}

Editor: Dr. Asep Hidayat

Korespondensi penulis: Reny Sawitri* (E-mail: sawitri.reny@yahoo.co.id)

Kontribusi penulis: RS: sebagai kontributor utama, menulis dan memperbaiki draft publikasi SI: memperbaiki draft publikasi; NMH: sebagai anggota tim penelitian; MB dan Y: sebagai kontributor anggota 


\section{PENDAHULUAN}

Siamang (Symphalangus syndictylus, Raffles 1821) termasuk satwa primata yang dilindungi di Indonesia, terdaftar dalam IUCN Red List dengan kategori genting (endangered) (Nijman \& Geissman, 2008; IUCN, 2014), namun belum termasuk dalam 25 daftar jenis primata yang tinggi tingkat keterancamannya (Mittermier et al., 2006). Keterancaman habitat siamang terus berlangsung seiring laju degradasi dan deforestasi hutan yang diperburuk oleh perburuan dan perdagangan ilegal (Yanuar, 2009), sehingga jenis ini termasuk dalam Appendix I CITES (Convention on International Trade in Endangered Species of Wild fauna and Flora). Menurut IUCN (2014), habitat siamang sudah berkurang $70-80 \%$ dan populasi siamang menurun 50\% (Hance, 2015).

Habitat siamang di Sumatera Barat terletak di kawasan hutan seluas 348.124,1 ha yang berada dibagian Taman Nasional Kerinci Seblat (TNKS) dan secara administratif berada di Kabupaten Pesisir Selatan. Penyusutan luas hutan primer di Sumatera Barat dari tahun 2002-2009 adalah $728.904,96$ ha $(2,99 \%)$, dimana seluas 23.438 ha sudah berubah menjadi lahan budidaya pertanian (BPKs, 2011). Perubahan hutan primer menjadi areal budidaya menyebabkan terjadinya mosaik atau fragmentasi habitat siamang di TNKS terutama di wilayah Pesisir Selatan. Hal ini mempengaruhi sebaran siamang yang secara alamiah dijumpai pada ketinggian $300 \mathrm{~m}$ dpl sampai mencapai $1.500 \mathrm{~m} \mathrm{dpl}$ (Gron, 2008).

Penggunaan lahan di desa-desa sekitar TNKS sebagai daerah penyangga terdiri dari areal berhutan 13.441 ha $(30,16 \%)$, hutan rakyat 16.111 ha $(36,15 \%)$ kebun agroforestri 1.114 ha $(2,5 \%)$ dengan sedikit lahan terlantar $1,29 \%$ (Bismark, Sawitri \& Heriyanto, 2014). Pola pemanfaatan lahan daerah penyangga dan pengaturan zonasi TNKS memberikan ruang untuk perlindungan populasi siamang di kawasan TNKS yang berbatasan dengan daerah penyangga.

Penelitian ini bertujuan untuk mengetahui habitat siamang di kawasan terdegradasi TNKS, dan kepadatan populasinya dengan melihat kenyataan bahwa di kawasan TNKS masih ada pemanfaatan lahan oleh masyarakat untuk areal pertanian seperti kebun agroforestri dan kebun tanaman gambir (Bismark et al., 2014) yang akan berpengaruh pada aktivitas pergerakan populasi siamang. Pola pengelolaan lahan di daerah penyangga diharapkan mampu mendukung habitat dan kelestarian populasi siamang.

\section{BAHAN DAN METODE}

\section{A. Waktu dan Lokasi Penelitian}

Penelitian dilakukan di dalam zona rimba, zona pemanfaatan dan zona rehabilitasi kawasan TNKS. Disamping itu, lokasi penelitian juga dilakukan di daerah penyangga yang termasuk Nagari Tanjung Gadang, Kecamatan Sutera; Nagari Air Haji, Kecamatan Linggo Sari Baganti, dan Nagari Lumpo, Kecamatan IV Jurai Wilayah Kabupaten Pesisir Selatan, Sumatera Barat. Penelitian dilakukan pada bulan September dan November 2015.

\section{B. Bahan dan Alat Penelitian}

1. Pengumpulan Data

Habitat yang terdegradasi di kawasan hutan TNKS diketahui melalui pengecekan pengolahan data citra digital dengan tahapan sebagai berikut: 1) data citra digital dari Google Maps di-copy dengan menggunakan cara printscreen, dan 2) dilakukan penentuan ketepatan letak koordinat dengan menggunakan titik di lapangan sebagai Ground Control Point (GCP) di peta vegetasi tutupan lahan (Jinarto \& Boer, 2009). Selanjutnya, dilakukan pengecekan kondisi lapangan di lokasi sekitar kelompok siamang berada dalam areal lingkaran contoh dengan jarijari lingkaran antara $500-1.000 \mathrm{~m}$ 
(Bismark, 2011). Jarak mosaik di kawasan hutan dilakukan dengan pengukuran mosaik satu dengan lainnya. Di mosaik hutan primer dilakukan pencatatan jenis tumbuhan, tinggi dan diameter batang yang merupakan komunitas vegetasi penyusun habitat dalam plot pengamatan 20x20 m sebanyak 14 sampel plot. Pencatatan vegetasi hanya dilakukan di mosaik hutan primer, hal ini didasarkan pemanfaatan kawasan ini sebagai tempat tidur, bersosialisasi dan mencari pakan; sedangkan tipe ekosistem lainnya hanya digunakan sebagai tempat bersosialisasi dan mencari pakan. Di daerah penyangga, pada kebun agroforestri dilakukan pengamatan dalam plot 50x50 m sebanyak empat sampel plot.

Penelitian populasi siamang dilakukan dengan metode Point Centre Count (PCC) dalam areal contoh (Hutto, Pletschet \& Hendricks, 1986). Kelompok siamang yang bersuara dalam cakupan lingkaran contoh dengan radius 750 meter, dicatat dan ditentukan sebaran dan jaraknya. Pengukuran jarak dilakukan dengan titik-titik koordinat GPS pada tujuh titik pengambilan contoh yang berbeda di lima lokasi dengan koordinat $\mathrm{S}$ $1^{\circ} 32^{\prime} 28,96^{\prime \prime}$ E $100^{\circ} 41^{\prime} 48,52^{\prime \prime}, \quad$ S $1^{\circ} 30^{\prime} 35,40^{\prime \prime}$ E $100^{\circ} 43^{\prime} 17^{\prime \prime}$ dan S $1^{\circ} 29^{\prime} 37,40^{\prime \prime}$ E $100^{\circ} 44^{\prime} 10,70^{\prime \prime}$ masingmasing pada ketinggian $245 \mathrm{~m}$ dpl, $297 \mathrm{~m}$ dpl dan $450 \mathrm{~m} \mathrm{dpl}$, serta 2 lokasi pada ketinggian $900 \mathrm{~m}$ dpl yaitu $\mathrm{S} 1^{\circ} 31^{\prime} 22,10^{\prime \prime}$ E 100 ${ }^{\circ} 43^{\prime} 40,6^{\prime \prime}$ dan $S 1^{\circ} 31^{\prime} 22,6^{\prime \prime}$ E $100^{\circ} 43^{\prime} 48,0^{\prime \prime}$. Tutupan lahan di lokasi penelitian sebagaimana Gambar 1 .

Pencatatan suara siamang dan jumlah kelompok di tiap titik pengamatan di lakukan dari jam 05.30-09.15 WIB. Metode pencatatan suara adalah focal instantaneous sampling (Martin \& Bateson, 2007), dimana puncak siamang bersuara (great call) dapat terjadi pukul 09.00-10.00 WIB dan kemungkinan siamang bersuara lebih satu kali dalam tiga hari adalah 0,535 (O' Brien et al., 2004). Populasi siamang dihitung berdasarkan jumlah kelompok dalam areal contoh dengan radius efektif yang didapat dari angka rata-rata jarak kelompok bersuara ke titik pusat lingkaran. Dalam penelitian ini, angin, temperatur dan hujan dianggap tidak mempengaruhi angka hasil penelitian populasi (O’ Brien et al., 2004).

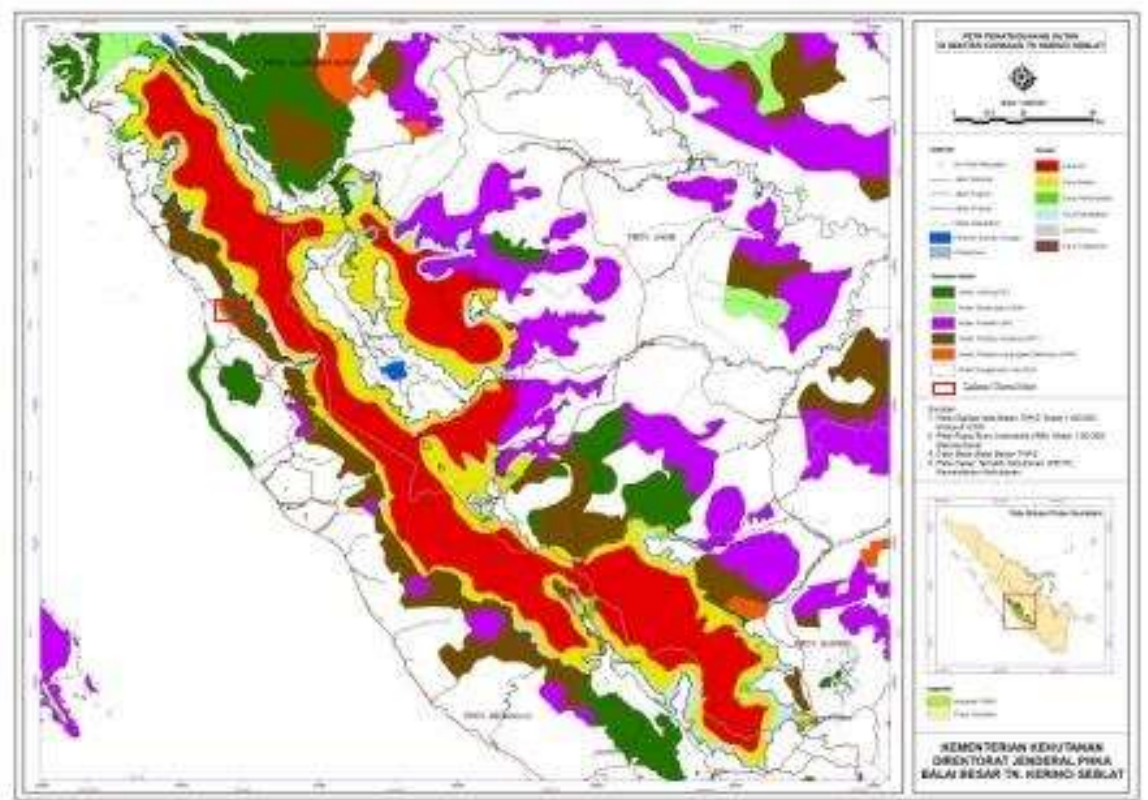

Gambar (Figure) 1. Tutupan lahan dan lokasi penelitian (Land cover and research areas) 


\section{Analisis Data}

Pengumpulan data vegetasi dilakukan dengan metode analisis vegetasi di kawasan hutan primer dan daerah penyangga TNKS, secara diskripsi berdasarkan komposisi floristik vegetasi yaitu dengan membuat daftar jenisnya (Martono, 2002). Data vegetasi yang diperoleh dari kawasan hutan primer dianalisis untuk mendapatkan nilai kerapatan relatif, frekuansi relatif dan dominansi relatif. Jenis pohon yang dominan diketahui melalui Index Nilai Penting (INP), sedangkan keanekaragaman jenis diketahui dengan Indeks Keanekaragaman Shannon - Wiener (Soerianegara \& Indrawan, 2005).

Luasan mosaik dan jarak antar mosaik di hutan primer didapatkan melalui perhitungan matematik, kemudian dianalisis secara deskriptif kuantitatif. Hasil pengamatan di lapangan disajikan dalam tabulasi data menurut waktu pengamatan, jumlah individu yang teramati dan ketinggian lokasi. Ukuran kelompok dihitung menurut persamaan (Sultan, Mansjoer \& Bismark, 2009).

Data vegetasi dan pemanfaatan lahan masyarakat yang termasuk daerah penyangga TNKS dianalisis secara deskriptif kuantitatif sehingga diketahui jenis tanaman di kebun agroforestri dan kerapatannya, serta jarak dari batas kawasan. selanjutnya dikelompokan menurut zonasi atau jalur berdasarkan daerah jelajah siamang di luar kawasan hutan.

\section{HASIL DAN PEMBAHASAN}

\section{A. Habitat Siamang di kawasan hutan TNKS}

Fragmentasi merupakan peristiwa terfragmennya habitat alami dan ekosistem menjadi fragmen-fragmen (Gunawan \& Prasetyo, 2013; Mullu, 2016). Kawasan hutan TNKS di Pesisir Selatan-Sumatera Barat yang merupakan habitat alami siamang telah terfragmentasi karena aktifitas pertanian dan perkebunan masyarakat secara ilegal di dalam kawasan (Abood, Lee, Burivalova, Garcia-Ulloa \& Koh, 2015). Kegiatan perambahan hutan tersebut akan berdampak pada terbentuknya fragmen atau mosaik (Newman, Laren \& Wilson, 2014). Degradasi dan fragmentasi hutan akan menyebabkan terjadinya isolasi habitat, penurunan daya dukung alam serta meningkatkan efek tepi sebagai akibat dari semakin luasnya pinggiran hutan yang terbuka (Sulistyadi, Kartono \& Maryanto, 2013). Isolasi habitat disebabkan oleh populasi satwa liar termasuk siamang yang menghuni area yang sempit dengan kondisi daya dukung yang sangat terbatas sehingga pertumbuhan populasinya kurang optimum karena harus mampu beradaptasi dengan perubahan ekosistemnya.

Mosaik di habitat siamang teridentifikasi berupa empat tutupan lahan, terdiri atas hutan primer, hutan sekunder, kebun agroforestri dan kebun gambir (Gambar 2).

Mosaik tipe ekosistem hutan dan jarak antar mosaik, tercantum pada Tabel 1. Mosaik hutan primer yang terbentuk di kawasan hutan memiliki luas bervariasi antara 6,6 ha sampai 78,1 ha, dan jarak antara mosaik sekitar $200 \mathrm{~m}$ sampai 880 m. Mosaik hutan yang terdegradasi menjadi hutan sekunder, kebun agroforestri dan kebun gambir memiliki luasan yang lebih sempit dan jarak antar mosaik yang lebih dekat. Jarak ini terkait dengan daya dukung habitat satwa yang berdampak terhadap keanekaragaman jenis mamalia (Ariyanti, 2016). 


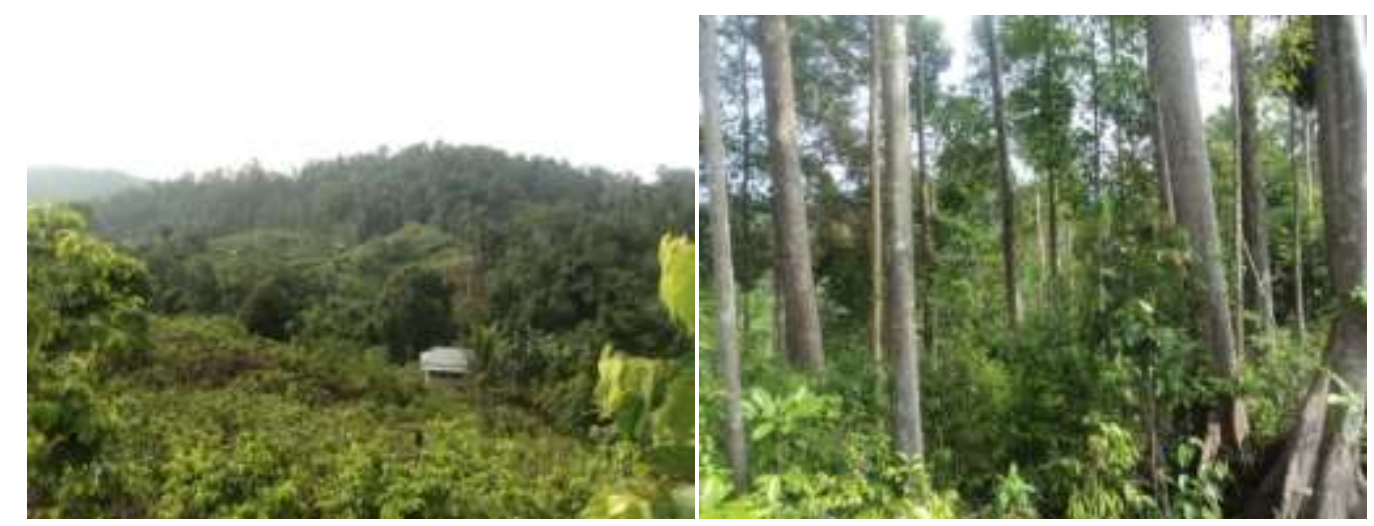

Gambar (Figure) 2. Tutupan lahan kebun gambir dan kebun agroforestri di Taman Nasional Kerinci Seblat (Land cover of white catechu culvation and agroforestry farming in Kerinci Seblat National Park)

Tabel (Table) 1. Mosaik hutan di habitat siamang, Taman Nasional Kerinci Seblat (Mosaic forest in the gibbon habitat, Kerinci Seblat National Park)

\begin{tabular}{clcc}
\hline No. & \multicolumn{1}{c}{$\begin{array}{c}\text { Tipe ekosistem } \\
\text { (Ecosystem types })\end{array}$} & $\begin{array}{c}\text { Luas (Areas) } \\
(\mathrm{ha})\end{array}$ & $\begin{array}{c}\text { Jarak (Distance) } \\
(\mathrm{m})\end{array}$ \\
\hline 1. & Hutan primer (Primary forest) & 29,30 & 486,70 \\
2. & Hutan sekunder (Secondary forest $)$ & 7,90 & 458,75 \\
3. & Kebun agroforestry (Agroforestry land) & 11,70 & 368,75 \\
4. & Kebun gambir (White catechu cultivation) & 7,80 & 202,50 \\
\hline
\end{tabular}

Rata-rata mosaik hutan primer di habitat siamang adalah 29,3 ha dengan jarak antara satu mosaik dengan yang lain hampir 486,7 m. Rata-rata luas mosaik hutan sekunder rata-rata adalah 7,9 ha, kebun agroforestri 11,7 ha dan kebun gambir 7,8 ha. Mosaik hutan primer seluas 30 ha masih menyediakan daerah jelajah bagi satwa arboreal folivorous dengan daerah jelajah 30-50 ha (Fuentes, 2002). Daerah jelajah tergantung pada kepadatan populasi dan pohon pakan, dalam hal ini daerah jelajah siamang lebih besar dari Symphalangus lainnya (McConkey \& Chivers, 2007).

Mosaik habitat siamang dengan beberapa tipe vegetasi hutan sekunder, kebun agroforestri dan kebun gambir tidak menjadi faktor penting bagi kelompok siamang karena siamang lebih toleran terhadap kerusakan habitat dan kehadiran manusia (Yanuar, 2009) seperti berladang atau berdekatan dengan rumah ladang. Mosaik hutan primer dengan luas lebih kecil dari 12 ha tidak mencukupi untuk teritorial, namun keberadaan hutan sekunder, kebun agroforestri dan kebun gambir akan dimanfaatkan oleh siamang untuk mencari pakan pucuk daun dari pohon di kawasan tersebut (Yanuar \& Chivers, 2010). Adaptasi dan toleransi terhadap fragmentasi kawasan hutan, siamang dapat menggunakan hutan sekunder sekitar teritorinya atau vegetasi koridor antar mosaik vegetasi habitat.

Di habitat terfragmentasi seperti di hutan terganggu akibat kegiatan manusia ataupun di hutan bekas kebakaran (Sibarani \& Andayani, 2013), siamang dapat beradaptasi dalam suatu populasi dengan kondisi yang relatif normal, baik rasio jenis kelamin, kelas umur maupun ukuran kelompok. Hal ini dimungkinkan karena perilaku makan siamang adalah daun, buah dan bunga (Permatasari, Setiawan \& Darmawan, 2017), walaupun pada waktu beradaptasi dapat memakan buah lebih banyak (72,5\%) daripada daun $(23,5 \%)$ (Christyani, 2014), namun siamang akan memakan lebih banyak 
daun apabila ketersediaan buah sedikit (Elder, 2013).

\section{B. Vegetasi}

Di kawasan hutan terdegradasi, mosaik hutan primer memiliki indeks keragaman jenis $\left(\mathrm{H}^{\prime}\right)$ pohon yang masih tinggi yaitu 3,06 dengan kerapatan pohon 600 pohon per ha (Tabel 2).

Keragaman jenis pohon yang tinggi sangat dibutuhkan siamang untuk melakukan aktivitas harian seperti tempat mencari pakan, tidur, beristirahat, bermain, berpindah dan bersuara serta tempat berlindung dan tempat berkembang biak (Master, Kanedi, Harianto, Prasetyaningrum \& Nurcahyo, 2013; Sari \& Harianto, 2015; Permatasari et al., 2017). Lokasi mencari pakan primata terletak dibagian tengah dan bagian atas tajuk sekaligus sebagai tempat tidur (Suyanto, Sinaga \& Sain, 2009). Jumlah pohon pakan yang dikunjungi berkisar 7-23 pohon per hari dengan jauh perjalanan (day range) 620-1.900 $\mathrm{m}$ per hari (McConkey \& Chivers, 2007). Pohon sebagai tempat tidur dipilih dengan ketinggian yang cukup tinggi dan tajuk yang lebar agar memberikan rasa aman bagi siamang dalam mengamati teritorinya (Yuliana, 2011). Disamping itu, hutan primer yang memiliki tajuk kontinyu berperan penting bagi siamang dalam melakukan pergerakan dengan cepat untuk berayun dari pohon ke pohon lain karena satwa ini jarang turun ke lantai hutan (Sultan et al., 2009; Mubarok, 2012).

Tingkat pancang didominasi sembilan jenis tumbuhan dengan indeks keragaman jenis (H') 2,1 dan kerapatan 3.067 individu per ha. Tingkat semai di dominasi 11 jenis dengan indek keragaman (H') 2,35 dan kerapatan 13.333 semai per ha, terdiri dari famili Dipterocarpaceae, Sapotaceae, Rosaceae, Lauraceae, Fagaceae dan Anacardiaceae. Jumlah terbanyak adalah semai Camnosperma auriculate (Blume) Hook.f. (2.675 per ha), famili Anacardiaceae (2.500 per ha), Quercus sp (833 per ha), Mangifera $s p$ (833 per ha) dan Shorea roxburghii G. Don (1.667 per ha).

Jumlah semai dari 11 jenis yang dijumpai di habitat siamang mengindikasikan adanya peran siamang dalam penyebaran biji tumbuhan sumber pakan yang dimakan melalui feces (McConkey, 2005), dan proses pertumbuhan tanaman melalui regenerasi dan suksesi hutan (Santosa, Nopiansyah, Mustari \& Rahman, 2010). Atmanto, Dewi \& Nurcahyani (2014) menyatakan bahwa biji tumbuhan yang ditemukan dalam feces siamang adalah 30 dari 37 sampel, dan sisanya hanya terdiri dari dedaunan. Dari 30 sampel yang berisi biji-bijian, 23 sampel mengandung berbagai macam jenis tumbuhan dan tujuh sampel hanya biji Ficus spp. Hal ini sejalan dengan penelitian Kuswanda dan Garsetiasih (2016), jenis-jenis pakan buah-buahan siamang di Cagar Alam Sipirok diantaranya adalah andarasi (Ficus congesta Roxb), asam hing (Dracontomelon dao Merr. \& Rolfe), cempedak (A. integer Merr), teurep (A. elasticusReinw.), pegepege (Ficus tenuicuspidata Corner.), dan handis (Garcinia celebica L.). Ficus termasuk marga Moraceae yang merupakan jenis kunci dan memiliki fungsi yang sangat penting di ekosistem hutan tropis sebagai sumber pakan satwa (Sathish, Viswanath, Kustalappa, Jagadish \& Ganeshaiah, 2013).

Siamang menyebarkan biji sedikit di sekitar pohon induk $(0,7 \%)$, dan $90 \%$ menyebarkannya melalui feces dengan jarak lebih $100 \mathrm{~m}$ dari pohon induk (McConkey \& Chivers, 2007). Di Resort Way Kanan, Taman Nasional Way Kambas, penyebaran biji oleh siamang berkisar antara 0-385 meter (Atmanto et al., 2014). Siklus floristik tidak berpengaruh nyata terhadap perilaku makan siamang karena siamang menyeleksi jenis pakan secara seimbang sepanjang tahun, seperti akhir musim kering pohon berdaun muda dan berbunga. 
Tabel (Table) 2. Jenis tumbuhan tingkat pohon dengan kerapatan jenis di atas 10 pohon per ha (Tree species with density more than 10 trees per hectare)

\begin{tabular}{llcr}
\hline No & \multicolumn{1}{c}{ Nama Jenis (Species) } & $\begin{array}{c}\text { Kerapatan jenis pohon, } \\
\text { (Tree species density, per ha) }\end{array}$ & $\begin{array}{r}\text { INP*) } \\
(I V I)\end{array}$ \\
\hline 1 & Maasia hypoleuca (Hook.f. \& Thomson) Mols & 42 & 14,42 \\
2 & Camnosperma auriculatum (Blume) Hook.f. & 67 & 17,71 \\
3 & Quercus sp & 17 & 9,09 \\
4 & Palaquium hexandrum (Griff) Baill & 17 & 9,32 \\
5 & Artocarpus sp. & 42 & 16,94 \\
6 & Garcinia sp. & 33 & 19,62 \\
7 & Palaqium gutta (Hook) Baill. & 33 & 22,19 \\
8 & Litsea roxburghii Hassk & 33 & 22,19 \\
9 & Shorea leprosula Miq. & 17 & 6,52 \\
10 & Shorea bracteolata Dyer & 67 & 23,59 \\
11 & Vatica rassak (Korth.) Blume & 17 & 7,74 \\
\hline
\end{tabular}

Keterangan (remarks): ${ }^{*}$ Indeks nilai penting, important value index

Di kawasan hutan sekunder TNKS, beberapa jenis pohon yang dimakan siamang adalah bagian daun, buah dan bunga dari jenis-jenis Polyalthia hypoleuca Hook.f.\& Thomson, Artocarpus sp., Garcinia sp., dan Nephelium mutabile L. (Master et al., 2013). Kebun agroforestri di dalam kawasan dimanfaatkan siamang untuk mencari pakan dan beristirahat di waktu siang untuk menghindari terik matahari dengan turun ke bagian tajuk paling rendah dan terbuka, namun siamang juga memanfaatkan kebun gambir untuk turun melewati tanaman gambir dan berpindah tempat, sehingga kebun gambir ini juga berfungsi sebagai koridor hutan primer (Ariyanti, 2016).

\section{Populasi}

Jumlah kelompok yang bersuara (great call) dalam waktu pengamatan di sembilan lokasi lingkaran contoh berdiameter $1.000 \mathrm{~m}$ teridentifikasi 36 kelompok siamang (Tabel 3).

Jarak kelompok ke pusat lingkaran contoh bervariasi antara 200-1.000 m dengan rata-rata $705 \mathrm{~m} \quad(\mathrm{n}=9)$. Berdasarkan jarak kelompok ke pusat lingkaran maka luas areal contoh adalah 156,15 ha atau setiap kelompok mempunyai areal sekitar 22,23-78,08 ha, rata-rata $40,9 \pm 17,7 \quad(\mathrm{n}=9)$ ha per kelompok. Berdasarkan angka ini maka rata-rata kepadatan populasi siamang adalah 2,45 kelompok per $\mathrm{km}^{2}$ atau 8,4 individu per ha.

Tabel (Table) 3. Jumlah kelompok menurut waktu bersuara dan ketinggian tempat (Number of groups based on time of great call and site altitude).

\begin{tabular}{lccccc}
\hline $\begin{array}{c}\text { Jam pengamatan } \\
\text { (Observation time, WIB) }\end{array}$ & $05.00-5.30$ & $05.30-06.00$ & $07.35-08.00$ & $08.45-9.00$ & $09.00-9.15$ \\
\hline $\begin{array}{l}\text { Jumlah kelompok } \\
\text { (Number of }\end{array}$ & 3 & 4 & 2 & 7 & 3 \\
$\begin{array}{l}\text { groups) } \\
\text { individu (Individual) }\end{array}$ & - & & & & \\
& - & 6 & - & 6 & - \\
& 3 & 15 & - & - & - \\
Jumlah (Total) & 297 & 450 & 900 & 900 & 245 \\
Ketinggian lokasi & & & & & \\
$\begin{array}{l}\text { (Altitude) } \\
\text { m dpl }(m \text { asl) }\end{array}$ & & & & & \\
\hline
\end{tabular}


Populasi siamang dijumpai pada ketinggian $>300 \mathrm{~m} \mathrm{dpl}$, namun jarang ditemukan pada ketinggian $>1.500 \mathrm{~m} \mathrm{dpl}$ (Gron, 2008). Sebaran dan populasi siamang juga dipengaruhi ketersedian pakan (Sari \& Herianto, 2015). Di lokasi penelitian, jumlah kelompok lebih banyak dijumpai pada lokasi dengan ketinggian $>450 \mathrm{~m}$ dpl (Tabel 3). Pada ketinggian 900 $\mathrm{m}$ dpl, kelompok siamang tertinggi tercatat pada waktu pengamatan 08.4509.00 WIB. Di areal dengan ketinggian $900 \mathrm{~m}$ dpl ini terdapat mosaik hutan primer yang luas (30-78,1 ha) dengan potensi tegakan 600 pohon per ha yang menyediakan pohon sebagai tempat tidur dan sumber pakan bagi siamang. Pohon yang digunakan siamang untuk bersuara adalah pohon yang memiliki tinggi total $39,18 \mathrm{~m}$ dan tinggi bebas cabang 21,67 $\mathrm{m}$ dengan lebar tajuk 19,33 m. Sebesar 90\% pohon tempat bersuara berada di tepi wilayah teritori, dan $66,1 \%$ pohon berdekatan dengan pohon buah sumber pakan sekaligus menunjukan pertahanannya terhadap teritori (Master et al., 2013).

Penelitian populasi siamang dengan menghitung kelompok yang bersuara dalam areal contoh dengan radius yang optimal sangat dipengaruhi oleh waktu pengamatan yang sesuai dengan calling behaviour, ketinggian tempat, kerapatan pohon pakan dan luas hutan primer yang tersedia sebagai teritorinya. Ketinggian lokasi berpengaruh positif terhadap populasi siamang $(\mathrm{r}=435)$, di Hala-Bala Wildlife Sanctuary pada ketinggian 500$700 \mathrm{~m}$ dpl (Nongkaew, Bumrungsari, Brockelmam, Savini, Pattanavibool \& Thong-Ari, 2018). Di Cagar Alam Sipirok dijumpai kepadatan populasi siamang 3,71 kelompok per $\mathrm{km}^{2}$ pada ketinggian $1.200 \mathrm{~m}$ dpl (Kwatrina, Kuswanda \& Setyawati, 2013), dan kepadatan populasi siamang di Stasiun Riset Way Canguk, Taman Nasional Bukit Barisan Selatan (TNBBS) berkisar 11 kelompok per $\mathrm{km}^{2}$ dengan jumlah individu 2,7 individu per kelompok (O'Brien \& Kinnard, 2010). Hasil penelitian Sibarani \& Andayani
(2013) menyatakan bahwa populasi pada lokasi bekas kebakaran maupun di tempat yang tidak terganggu memiliki kepadatan populasi yang tidak berbeda secara signifikan yakni 3,85 kelompok per $\mathrm{km}^{2}$ dan 3,86 kelompok per $\mathrm{km}^{2}$. Populasi siamang sejumlah 8,4 individu per $\mathrm{km}^{2}$ dengan selang kepadatan normal di kawasan hutan yang telah terfragmentasi dari sebagian besar hutan primer menjadi hutan sekunder atau kebun agroforestri menunjukan bahwa siamang sangat toleran terhadap perubahan vegetasi habitat.

\section{ASPEK KONSERVASI}

Lokasi penelitian dengan tujuh areal contoh berada di Zona Rimba, Zona Pemanfaatan Terbatas dan Zona Rehabilitasi TNKS Wilayah Kabupaten Pesisir Selatan Sumatera Barat. Pada tahun 2013 terjadi revisi zonasi TNKS, zona pemanfaatan dikurangi dan ditingkatkan menjadi zona rimba, sedangkan zona rimba yang terfragmentasi diubah menjadi zona rehabilitasi, serta terjadi penambahan luas zona khusus, terutama areal pemukiman suku asli melayu. Masyarakat di zona khusus umumnya berkebun melalui sistem agroforestri dengan jenis tanaman buahbuahan (durian, manggis, duku, dan nangka), tumbuhan kayu dan gambir. Pada zona rehabilitasi telah dilakukan penanaman dengan jenis lokal sehingga akan memperbaiki habitat siamang dan satwa lainnya (Bismark et al., 2014).

Predator merupakan ancaman bagi primata, sehingga sistem pertahanan oleh siamang jantan menjadi penting, termasuk pertahanan sumber pakan dari kompetitor (Bahri, 2012). Perilaku bersuara adalah salah satu bentuk dan upaya mempertahankan sumber pakan dalam teritori. Di lokasi penelitian tidak ada informasi perburuan, walaupun masih ditemukan di beberapa pasar satwa penjualan anak siamang dengan harga Rp1.500.000Rp3.500.000.

Siamang di TNKS dapat beradaptasi dengan habitat terdegradasi, ladang dan 
kebun agroforestri yang ditunjukan dengan kondisi populasi dalam selang kepadatan normal. Selain itu, penatagunaan lahan di daerah penyangga untuk mendukung perluasan habitat siamang dengan areal berhutan dan kebun agroforestri yang diambil hasilnya berupa kayu, buah-buahan dan hasil hutan bukan kayu (HHBK) (Kolbinar \& Hutagalung, 2016). Tanaman tersebut antara lain jati (Tecton agrandisL.f), jabon (Anthocephalus cadamba (Roxb) Miq), dan pulai (Alstonia scholaris L.R. Br) dengan kerapatan rata-rata 80 pohon per ha (Tabel 4). Selain itu di tanam juga tanaman sela berupa coklat (Theobroma cacao L.) dan kopi (Coffeasp.).

Tegakan pohon pada kebun agroforestri berdiameter $10-60 \mathrm{~cm}$ dengan tinggi 8-24 $\mathrm{m}$ dimanfaatkan siamang untuk mencari pakan dan beristirahat (Kartasasmita, 1976). Perilaku makan siamang sebagai penyebar biji buahbuahan pohon pakan yang memungkinkan mem-berikan dampak positif bagi pengkayaan jenis di kebun agroforestri masyarakat karena menjadi bagian perluasan daerah jelajah bagi siamang. Perilaku ini dapat meningkatkan keragaman biodiversitas di hutan sekunder dengan jenis pakan siamang. Aspek perlindungan habitat sangat penting dilakukan terutama pengaturan bentuk pemanfaatan lahan di zona pemanfaatan atau zona khusus untuk mempertahankan populasi satwa arboreal di kawasan TNKS. Lokasi kebun agroforestri dalam suatu pola pemanfaatan lahan di beberapa desa yang termasuk kawasan penyangga TNKS dapat dilihat pada Tabel 5.

Berdasarkan pola di atas terdapat beberapa satwa selain siamang yang menjadikan hutan sekunder dan kebun agroforestri sebagai habitat, seperti tapir (Tapirus indicus Desmarest, 1819 ), babi hutan (Sus scrofa Linnaeus, 1758), rusa (Cervus unicolor Kerr, 1792), trenggiling (Manis javanica Desmarest, 1822), simpai (Presbytis melalophos Raffles, 1821), lutung ( $P$. cristata, Gray 1843), landak (Hystrix brachyura Linnnaeus, 1758), bajing kelapa (Callosciurus notatus Boddaert, 1785) dan monyet ekor panjang (Macaca fascicularis Raffles, 1821). Beberapa diantara satwaliar ini dianggap hama oleh petani karena merusak atau mengganggu tanaman (Sawitri, Bismark, Heriyanto \& Kwatrina, 2016), sehingga diperlukan sosialisasi kepada masyarakat akan pentingnya suatu lingkungan yang sehat dalam suatu kesatuan ekosistem (Asmi, Darusman, Ichwandi \& Suharjito, 2019).

\section{KESIMPULAN DAN SARAN}

\section{A. Kesimpulan}

Habitat siamang di Taman Nasional Kerinci Seblat Wilayah Kabupaten Pesisir Selatan Sumatera Barat relatif terfragmentasi dan terdegradasi akibat perladangan ilegal yang mencapai pada ketinggian 900 $\mathrm{m}$ dpl. Akibat pembukaan lahan, mosaik hutan primer sebagai habitat siamang tersebar dan dikelilingi oleh hutan sekunder, kebun agroforestri dan kebun gambir.

Mosaik hutan primer sebagai habitat siamang mempunyai luas rata-rata 29,3 ha; hutan sekunder seluas 7,9 ha; kebun agroforestri seluas 11,7 ha dan kebun gambir seluas 7,8 ha. Populasi siamang pada habitat hutan primer yang terfragmentasi dengan jarak 486,7 $\mathrm{m}$ masih dalam kondisi normal, dengan kepadatan 2,45 kelompok per $\mathrm{km}^{2}$ atau sekitar 8,4 individu per $\mathrm{km}^{2}$. Hal ini didukung oleh kerapatan pohon yang cukup, sekitar 600 pohon per ha yang berfungsi sebagai tempat mencari pakan, tidur, beristirahat dan bersosialisasi. Tingginya kerapatan semai (13.333 semai per ha) untuk 11 jenis pohon mengindikasikan bahwa semai tersebut berasal dari biji buah yang dimakan siamang dan disebarkan melalui feces. Perilaku siamang sebagai penyebar biji akan meningkatkan biodiversitas melalui proses regenerasi dan suksesi hutan secara alami. 
Tabel (Table) 4. Jenis-jenis tanaman yang dibudidayakan dengan pola agroforestri di daerah penyangga (Crop species cultivated by agroforestry system in the buffer zone.)

\begin{tabular}{cll}
\hline No & \multicolumn{1}{c}{$\begin{array}{c}\text { Nama lokal } \\
\text { (Local name })\end{array}$} & \multicolumn{1}{c}{$\begin{array}{c}\text { Nama ilmiah } \\
\text { (Scientific name) }\end{array}$} \\
\hline 1 & Jati & Tectona grandis L.f. \\
2 & Jabon & Neolamarckia cadamba (Roxb.) Bosser. \\
3 & Pulai & Alstonia scholaris L.R. Br. \\
4 & Waru & Hibiscus tiliaceus L. \\
5 & Walik angin & Mallotus paniculatus (Lam) Mull. Arg. \\
6 & Terap & Artocarpus odoratissimus Blanco \\
7 & Bayur & Pterospermum javanicum Jungh. \\
8 & Kayumanis & Cinnamomum verum J. Presl. \\
9 & Jengkol & Archidendron pauciflorum (Benth.) l.C.Niesen \\
10 & Rambutan & Nephelium lappaceum L. \\
11 & Karet & Hevea brasiliensis Mull. Arg. \\
12 & Kemiri & Aleurites moluccana (L.) Willd. \\
13 & Durian & Durio zibethinus L. \\
14 & Manggis & Garcinia mangostana L. \\
15 & Nangka & Artocarpus heterophyllus Lam. \\
16 & Duku & Lansium parasiticum (Osbeck) K.C.Sahni \& Bennet. \\
17 & Jambu bol & Syzygium malaccense (L.) Merr. \& L.M.Perry \\
\hline
\end{tabular}

\section{B. Saran}

Untuk meminimalisir laju fragmentasi habitat siamang oleh masyarakat, maka Balai konservasi Sumber Daya Alam (BKSDA) Sumatera Barat dan Balai Besar TNKS bersama Satuan Kerja Pemerintah Daerah (SKPD) terkait harus melakukan perencanaan pengelolaan daerah penyangga sebagai perluasan habitat siamang. Salah satu rencana pengelolaan yang penting dilakukan adalah mengkaji penerapan pola-pola perhutanan sosial yang dapat dibangun di kawasan tersebut. Dengan penerapan pola perhutanan sosial, diharapkan habitat siamang di daerah penyangga dapat terselamatkan, dan bagi masyarakat mendapatkan manfaat secara ekonomi.

\section{UCAPAN TERIMA KASIH}

Ucapan terimakasih disampaikan kepada Kepala Balai Besar Taman Nasional Kerinci Seblat bersama jajaran petugas di lapangan dan masyarakat lokal yang telah memberikan informasi keberadaan satwa siamang di daerah penyangga, sehingga penelitian ini dapat dilaksanakan sebagaimana yang diharapkan. Penelitian ini dibiayai oleh dana DIPA tahun 2015 Pusat Penelitian dan pengembangan Hutan, Bogor.

\section{DAFTAR PUSTAKA}

Abood, S.A., Lee, J.S.H, Burivalova Z., Garcia-Ulloa, J., \& Koh, L.P. (2015). Relative contributions of logging, fiber, oilpalm, and mining industries to forestloss in Indonesia. Conservation Letters, 8, 58-67. Diakses dari http://doi.org/ 10.1111/conl.12013.

Ariyanti, E.S. (2016). Dampak perubahan ekosistem hutan menjadi agroforestri karet, kebun karet dan kebun kelapa sawit terhadap keanekaragaman jenis dan kelimpahan relatif kelelawar, studi di hutan harapat PT Restorasi EkoisiteIndonesia (REKI) dan Taman Nasional Bukit Duabelas, Jambi. (Thesis Master). Universitas Lampung, Bandar lampung.

Asmi, F., Darusman, D., Ichwandi, I., \& Suharjito. (2019). Mainstreaming community-based forest management 
in West Sumatra.: Social forestry argument, support and implementation. Forest and Society, 3(1), 77-96.

Atmanto, A.D., Dewi B.S., \& Nurcahyani, N. (2014). Peran siamang (Hylobates syndactylus) sebagai pemencar biji di Resort Way Kanan Taman Nasional Way Kambas Lampung. Jurnal Sylva Lestari, 2(1), 49-58.

Bahri, S. (2012). Kajian Jarak Gua Terhadap Keanekaragaman

Kelelawar Pemakan Serangga Di Stasiun Penelitian dan Pelatihan Konservasi Way CangukTaman Nasional Bukit Barisan Selatan. (Skripsi Sarjana). Universitas Lampung, Bandar Lampung.

Bismark, M. (2011). Prosedur operasi standar (SOP) untuk survey keragaman jenis pada kawasan konservasi. ITTO, $40 \mathrm{pp}$

Bismark, M., Sawitri R., \& Heriyanto N.M., (2014). Implementasi dan evaluasi kriteria dan indikator efektivitas pengelolaan kawasan konservasi. (LaporanPenelitian). Pusat Penelitian Hutan. Bogor.

Biro Penelitian, dan Kerjasama (BPKs). (2011). Kajian Perubahan Hutan Primer Pulau Sumatera.Universitas Gajah Mada. Yogyakarta.

Christyani, M. (2014). Kompetisi dan tumpeng tindih relung antara siamang (Symphalangus syndactylus) dan mamalia arboreal lain di Taman Nasional Bukit Barisan Selatan. (Skripsi Sarjana). Universitas Indonesia. Depok.

Doswald, N., Munroe R., Roe D., Giuliani A., Castelli, I., Stephens J., ........ Reid H. ( 2014). Effectiveness of ecosystem-based approaches for adaptation: review of the evidencebase. Climate and Development, 6, 117.

Elder, A.A. ( 2013). Competation among three primates species at Way
Canguk, Sumatra, Indonesia. (Desertasi Doktor). Stony Brook University, New York.

Fuentes, A. (2002). Patterns and trends in primate pair bonds. Jounal Primatology, 23(5), 953-978.

Gron, K.J. (2008, Mei 20). Primate fact sheets: Siamang (Symphalangus syndactylus) taxonomy, morphology and ecology. Diakses dari http://pin.primate.wisc.edu/factsheets /entry/siamang $>$.

Gunawan, H. \& Prasetyo, L.B. (2013). Fragmentasi hutan: Teori yang mendasari penataan ruang hutan menuju pembangunan berkelanjutan. Pusat Penelitian dan Pengembangan Konservasi dan Rehabilitasi. Bogor.

Hance, J. (2015, Agustus 9). Siamang owa besar sumatera yang terlupakan di dunia. Diakses dari http://www.Mongabay.co.id.

Hutto, L.R, Pletschet, S.M. \& Hendricks, P. (1986). A field radius point count method for non breeding and breeding season use. The Auk, 103, 593-60.

IUCN. 2014. IUCN Red List of Threatened Species. Diakses dari https://www.iucnredlist.org/

Jinarto, S., \& Boer, C. (2009). Studi fragmentasi habitat dan analisis sebaran sarang orangutan (Pongo pygmaeus morio Wen) di Taman Nasional Kutai, Kalimantan Timur. Jurnal Kehutanan Tropika Humida, 2(2), 204-209.

Kartasasmita, K. (1976). Pedoman inventarisasi flora dan ekosistem. Direktorat Jenderal Perlindungan Hutan dan Pelestarian Alam. Bogor.

Kolbinar, I., \& Hutagalung, S.S. (2016). Analisis kebijakan pelestarian damar di kabupaten Pesisir Barat (Studi terhadap agenda setting damar sebagai usaha perlindungan dan peningkatan kesejahteraan petani damar). Jurnal Ilmiah Administrasi Publik Pembangunan, 7(1), 27-34. 
Kuswanda, W., \& Garsetiasih. (2016). Daya dukung dan pertumbuhan populasi siamang (Hylobates syndactylus Raffles 1821) di Cagar Alam Dolok, Sipirok, Sumatera Utara. Buletin Plasma Nutfah, 22(1), 67-80.

Kwatrina R. T., Kuswanda, W. \& Setyawati, T. (2013). Sebaran dan kepadatan populasi siamang (Symphalangus syndactylus) di Cagar Alam Dolok Sipirok dan sekitarnya, Sumatera Utara. Jurnal Penelitian Hutan dan Konservasi Alam, 10(1), 81-91.

Martin, P., \& Bateson, P. (2007). Measuring behaviour an introductory guide. Cambridge University Press. Cambridge.

Martono, D.S. (2002). Analisis vegetasi dan asosiasi antara jenis-jnis pohon utama penyusun hutan tropis dataran rendah di Taman Nasional Gunung Rinjani Nusa Tenggara Barat. Agritek, 13(2), 18-27.

Master, J., Kanedi, M., Harianto, S.P., Prasetyaningrum, M.D., \& Nurcahyo, A. (2013). Karakteristik pohon yang digunakan dalam aktivitas harian siamang (Symphalangus syndactylus syndactylus Raflles, 1821) di Taman Nasional Bukit Barisan Selatan (TNBBS) Lampung. Dalam S. Dewi, H. Apkuanbo, \& S. Saidi (Eds.) Prosiding Seminar FMIPA Universitas Lampung (hal 9-14).

McConkey, K.R. (2005). Influence of faeces on seed removal from gibbon droppings in dipterocarps forest in Central Borneo. Journal of Tropical Ecology 21, 117-120.

McConkey, K.R., \& Chivers, D.J. (2007). Influence of gibbon ranging patterns on seed dispersal distance and deposition site in Bornean Forest. Journal of Tropical Ecology, 23, 269275.

Mittermier, R.A, Valladares-Padua, C., Rylands, A.B., Eudey, A.A.,
Butynski, T.M., Ganzhorn, J.U., ...... Walker, S. (2006). Primates in Peril: The Worlds 25 most endangered primates, 2004-2006. Primates Conservation, 20, 1-28.

Mubarok, A. (2012). Distribusi dan kepadatan simpatrikungko (Hylobatesagilis) dan siamang (Symphalangussyndactylus) di Kawasan Hutan batang Toru, Sumatra Utara. (Skripsi Sarjana). Institut Pertanian Bogor. Bogor.

Mullu, D. 2016. A review on the effect of habitat fragmentation on ecosystem. Journal of Natural Sciences Research, 6(15), 1-15.

Newman, M.E., MclLaren, K.P., \& Wilson, B.S. (2014). Assesing deforestation and fragmentation in a tropical moist forest over 68 years; the impact of road sand legal protection in the cockpit country, Jamaica. Forest Ecology and Management, 315, 138-152.

Nijman, V., \& Geissman. (2008, Agustus 1). Symphalangus syndactylus. In IUCN Red List of ThretenedSpecies. Version 2009.2. Diakses dari http://www.iucnredlist.org/

Nongkaew, S., Bumrungsari, S., Brockelmam, W.Y., Savini, T., Pattanavibool, A., \& Thong-Ari, S. (2018). Population density and habitat of siamang and agile gibbon in Bala Forest, SothernThailand. Natural History Bulletin of the Siam Society, 62(2), 117-130.

O' Brien, T.G., Kinnaird, M.F., Nurcahyo, A., Iqbal, M., \& Rusmanto, M. (2004). Abundance and distribution of sympatrik gibbons in thretened Sumatran in forest. International Journal of Primatology, 25(2), 267284.

O' Brien, T. G., \& Kinnaird, M. F. (2010). Demography of agile gibbons (Hylobates agilis) in lowland tropical rain forest of southern Sumatra, Indonesia: problem in paradise. 
International Journal of Primatology, 32(5), 1202-1217.

Permatasari, B.I., Setiawan, A., \& Darmawan, A. (2017). Diskripsi kondisi habitat siamang, Symphalangussyndactylus, di Hutan Lindung Register 28 Pematang Neba Kabupaten Tanggamus Lampung. Sripta Biologi, 4(4), 221-227.

Sari, E.M., \& Harianto, S.P. (2015). Studi kelompok siamang (Hylobates syndactylus) di Repong Damar Pahmungan Pesisir Barat. Jurnal Sylva Lestari, 3(3), 85-94.

Sathish, B.N., Viswanath, S., Kushalappa, C.G., Jagadish, M.R., \& Ganeshaiah, K.N. (2013). Comparative assessment of floristic structure, diversity and regeneration status of tropical rainforests of Western Ghatsof Karnataka, India. Journal of Applied and Natural Science, 5(1), 5157-164.

Sawitri, R., Bismark, M., Heriyanto, N.M., \& Kwatrina, R.T. (2016). Perkembangan pengelolaan daerah penyangga dan sumberdaya hutan Taman Nasional Kerinci Seblat. Dalam M. Bismark, \& E. Santoso (Eds.) Prosiding Seminar Membangun Hasil hutan Yang Tersisa. Bogor. Forda Press.

Santosa, Y., Nopiansyah, F., Mustari, A.H, \& Rahman, D.A. (2010). Penggunaan parameter morfometrik untuk pendugaan Siamang Sumatera. Jurnal Penelitian Hutan dan Konservasi Alam, 8(1), 25-33.

Sibarani, Mc., \& Andayani, N. (2013). Population study of siamang (Symphalangus syndactylus) in Way Canguk Bukit Barisan National Park. Wildlife Conservation Society. Direktorat Jenderal Pendidikan Tinggi. Diakses dari https://www. academia.edu/11113771/Population Study_of_Siamang_Symphalangus_s yndactylus_in_Way_Canguk_Bukit_-
Barisan_Selatan_National_Park.

Soerianegara, I., \& Indrawan, A. (2005). Ekologi Hutan Indonesia. Fakultas Kehutanan, Institut Pertanian Bogor, Bogor.

Sulistyadi, E., Kartono,A.P., \& Maryanto, I. (2013). Pergerakan lutung jawa Trachypithecus auratus (E.Geoffrey 1812) pada fragmen habitat terisolasi di Taman Wisata Alam Gunung Pancar (TWAGP) Bogor. Berita Biologi, 12(3), 383-394.

Sultan, K., Mansjoer, S.S., \& Bismark, M. (2009). Populasi dan distribusi ungko (Hylobates agilis) di Taman Nasional Batang Gadis, Sumatera Utara. Jurnal Primatologi Indonesia, 6(1), 25-31.

Suyanto, A., Sinaga, M.H., \& Sain, A. (2009). Mammals biodiversity in Tesso Nillo, Riau Province, Indonesia. Jurnal Zoo Indonesia,2,7988.

Yanuar, A. 2009. The population distribution and abundance of siamangs (Symphalangus syndactylus) and agile gibbons (Hylobates agilis) in westcentral Sumatra, Indonesia. Dalam S. Lappanand, \& D.J. Whittaker (Eds.) The Gibbons: New Perspectives on Small Ape Sociology and Population Biology. New York, Springer.

Yanuar, A., \& Chivers, D.J., 2010. Impact of forest fragmentation on ranging and homerange of siamang (Symphalangus syndactylus) and agile gibbons (Hylobates agilis). Dalam S. Gursky-Doyen, \& J. Supriatna (Eds.) Indonesiaan Primates. New York, Spinger.

Yuliana, R. (2011). Analisis habitat siamang (Hylobathessyndactilus) di Repong damarPekonPahmungan Kecamatan Pesisir Tengah Lampung Barat (Skripsi Sarjana). Universitas Lampung. Lampung. 